\title{
An ecological approach to the development of an active aging measurement in urban areas (AAMU)
}

\author{
Azadeh Lak ${ }^{1 *}$ D, Parichehr Rashidghalam', S. Nouroddin Amiri', Phyo K. Myint ${ }^{3}$ and Hamid R. Baradaran 3,4
}

\begin{abstract}
Background: An essential element in the process of "aging well" is the concept of Active Aging (AA). To propose an operational definition of Active Aging, the present study seeks to develop a new measurement tool through an ecological approach. The aim is to recognize significant indicators that play a role in assessing AA in urban areas.

Methods: This study was conducted through a two-phase process of consensus-building: 1) identifying a set of indicators that were likely candidates for inclusion based on literature review, and 2) a two-round modified Delphi survey using an international panel of academic experts in environmental sciences and gerontology to achieve consensus on the importance of the extracted indicators and validate the items. The panelists were asked to complete a researcher-developed questionnaire with an 11-point Likert scale based on the indicators derived in phase 1. Finally, the Delphi survey's valid indicators and criteria were utilized to develop the measurement tool.

Results: At the outset, a list of 111 indicators of AA was prepared through the desk study. A panel of 22 experts reviewed the extracted items and arrived at a consensus on 99 items in the first round and finalised in the second round. Thematic analysis of the panelists' open-ended responses revealed new concepts that would be explicitly considered by the consensus group. This developed measurement scale consists of five domains, i.e., individual, spatial, socio-economic, governance, and health-related, which contain 15 criteria and 99 indicators.

Conclusions: The present researchers have developed the active aging measure for urban settlements (AAMU), which can be used both by policy-makers and as an informal self-reported statement among the elderly. AAM's results in the elderly's residential environmental communities can improve policy-making to address urban design to sustain an active, healthy life among older people in urban environments.
\end{abstract}

Keywords: Active ageing measurement, Ecological approach, Delphi technique

\section{Background}

The issue of long-term care has always been at stake in policy-making concerning the resources necessary to fulfil the care needs of the elderly. Due to the increased life expectancy delayed health decline due to medical advances, a gradual shift in care focus has occurred. In

\footnotetext{
*Correspondence: A_Lak@sbu.ac.ir

${ }^{1}$ Faculty of Architecture and Urban Planning, Shahid Beheshti University, Tehran 1983963113, Iran

Full list of author information is available at the end of the article
}

some countries, such as those in the European Union, there is a tendency to combine social behaviour and long-term care (referred to as 'Active Aging') to promote healthy aging $[1,2]$. Active Aging (AA) can be defined as "the process of optimising opportunities for health, participation, and security to enhance the quality of life as people age" [3]. Central to this process is socially active engagement in different aspects of social, professional, and family life, including paid work, community activities, residential care, and leisure activities 
$[4,5]$ so that a harmonious relationship between life and activities could improve the health and well-being in old age [5, 6].

The idea of AA was initially proposed, emphasizing being active to maintain health and productivity [7]. Later on, it advocated for older adults' right to make personal decisions, remain independent, and enhance their quality of life $[3,5]$. Thus, although the elderly are not counted among the active labour force, they are considered contributors in their entire lives and encouraged to participate in various social and individual activities [8]. Recently, AA's primary focus has shifted from physical health and 'employability' to engage with life in general [9].

In line with this, research has adopted multidimensional definitions of Active Aging and addressed various issues, including subjective and objective perception of health, affective and cognitive factors, functionality, and social status [10]. Multiple variables of participation, such as leisure [11], social engagement [10], and lifelong learning [12], have also been taken into account.

The concept of AA is now widely used in policymaking regarding the aging population and is measured employing the Active Aging Index (AAI). Accordingly, AAI has been used since 2012 by the European Union $(E U)$ as a composite index, and its original purpose was ambiguous [13]. According to São José et al. (2017), AAI measures the level to which older people live independent lives, participate in paid employment and social activities, and their capacity to actively age. The index is constructed from 22 individual indicators grouped into four distinct domains in the $28 \mathrm{EU}$ countries. Each domain presents a different aspect of measuring older people's untapped potential for active and healthy ageing. They also argue that AAI, which is a narrowly conceptualised and under-theorised policy tool, is based on a restrictive model of Active Aging and serves the process of Model Aging. Furthermore, underlying AAI is a priori assumption concerning the capacity of older people in a European context as well as the activities and domains of life they tend to value. However, according to Foster and Walker (2015), we need to have new tools foster social inclusion, flexibility and respect for national and cultural diversity [14].

In reviewing the recent active aging assessment scales, We found a scale in Thailand containing the following domains: being self-reliant, being actively engaged with society, developing spiritual wisdom, building up financial security, maintaining a healthy lifestyle, engaging in active learning, and strengthening family ties to ensure care in later life [15]. This scale suggested culturespecific factors included to promote the elders' wellbeing. Recently, the UJACAS questionnaire is claimed as a scale to evaluate active aging from the elders' perspectives [16]. This questionnaire was developed based on four domains of active aging: the elders' goals, the elders' functional capacity, the elders' autonomy, and the elders' activities [16].

The present study seeks to develop a new measurement tool for AAI in urban areas. Against the background of emerging research interest in integrating Active Aging in long-term care policies by adopting an ecological approach to consider the community environments on active life among the elders. In this regard, it is aimed at providing an operational definition of AA through the Delphi method. As emphasised in the literature, the socio-cultural milieu is necessary to crossculturally develop social policies and conceptual frameworks for aging populations [17] in the current AA measurement. Thus, a significant issue in the literature could be resolved, i.e., the rough treatment of the notion of AA. If used to predict activity level, AA measurement could help monitor the Active Aging status among older persons and evaluate the effectiveness of policy and service changes applied to encourage Active life in urban communities.

\section{Methods}

According to Woodcock et al.(2020), a two-phase consensus-building approach was conducted: (1) identifying the list of features of measurement tools that were potential represents for inclusion based on importance (April-May 2019); (2) conduct of a modified two-round Delphi survey (June-August 2019). The Delphi method was chosen because it is one of the most suitable research approaches aimed at unknown subjects [18].

\section{Phase 1: identifying the candidate features to include in the measurement tool}

We extracted a list of criteria and indicators that could be proposed for the decisional operation of AA; all these indicators and criteria modified the Delphi study. We reviewed the existing literature in the development of AA measurement for improvement, including peerreviewed and grey literature. We started with articles recommended by members of the steering group in Lak et al. (2020). The authors checked the reference list of these articles to identify other relevant studies in the next step. Finally, the different aspects of Active Aging which have been discussed in the literature can be categorised in the 5P Model: 1) person (personal status); 2) process (socio-economic environment); 3) place (built environment); 4) policy-making (governance); and Prime (health) [19]. This process resulted in a list of extracted indicators for inclusion in the modified Delphi study. For each indicator, we applied the supporting literature to draft an explanation of what the measurement tool might include (see Fig. 1, Table 1). 


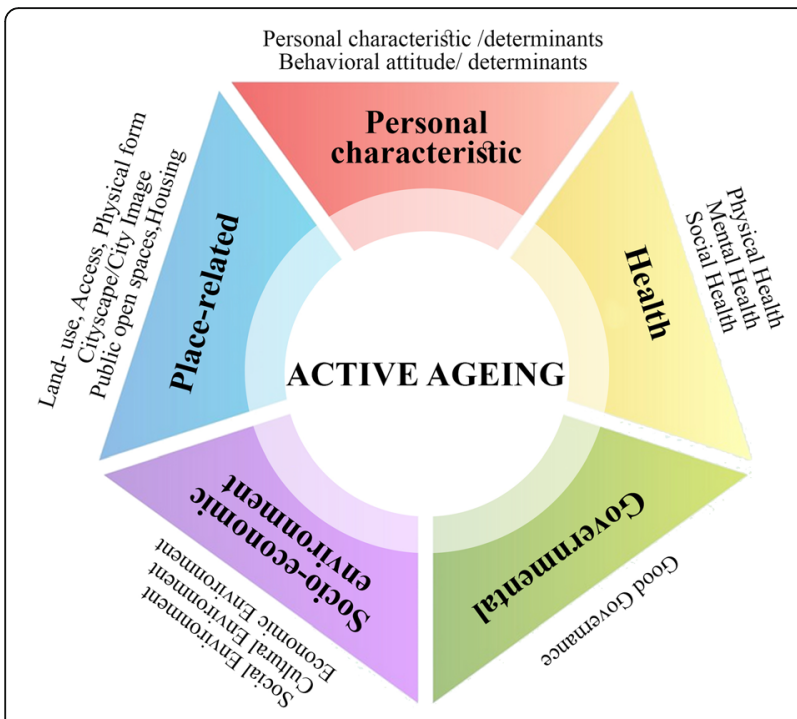

Fig. 1 The Active aging framework

Our Delphi questionnaire was developed using the indicators extracted from the literature in the Desk study. Likert-scale items were designed to collect both qualitative and quantitative data, and some open-ended questions were developed to allow for further qualitative input. Certain aspects of the topic were investigated through open questions. Using the Likert scale is a suitable tool for measuring the indicators and criteria in questions, and it helps to evaluate the level of consensus quickly. We used the 11-item Likert scale in this study, as Cronbach alpha coefficient is highest for 11-point Likert scale and superior to others [107].

First, a pilot study was conducted using four experts to examine the questions' comprehensibility and its usability. Also, the design of the study was validated by four experts as gerontologists and urban designers. The feedback from the pilot study was taken into account in the final version of the questionnaire. Some of the criteria were eliminated in this phase to reduce the final questionnaire items down to 111 . This process is shown in Fig. 2.

\section{Phase 2: consensus-building study to select and refine the indicators and criteria}

The Delphi technique [108] was applied to build consensus on which indicators from phase 11 were significant to include as features of a AA measurement tool, using two rounds of scoring and review by an expert panel over eight weeks.

The feedback process is integrated into the Delphi method. The first round results are revisited and possibly modified by the respondents in later phases when they have reviewed and considered the feedback of the other Delphi experts [109]. The characteristic of this method is that it ensures the anonymity of respondents. The administrator controls the feedback process, and there are several statistical techniques for interpreting the data [110]. As the Delphi procedure progresses, the respondents tend to present their opinions with more in-depth insight. Research has shown that a rational number of rounds, or iterations, to reach a consensus is usually two or three [18]. The process can be followed in Fig. 2.

A recent study has suggested that a panel of 10-18 experts is enough for a homogeneous sub-group [111]. However, if a Delphi study involves a range of reference groups, a more significant number of experts is usually needed. Qualitative research in social sciences usually requires $15-30$ experts [112], while it is quite common for other types of research to use $15-20$ respondents $[18,113]$.

For a heterogeneous sample, a group of 20-50 participants seems large enough to ensure variety in opinions and small enough to ensure consensus [114]. To achieve this number, we communicated with 45 experts around the world, and, finally, 22 experts agreed to participate in two rounds of research. In doing so, we sent the invitation email to the 45 experts we had identified along with the necessary information about the survey topic. A reminder was sent out two weeks after the initial request emails. The process was repeated three times in twoweek intervals, and, after the eighth week, 22 experts completed the survey in two rounds. As our expectation of the number of experts was met, the first round was finished. Next, an email was sent to the 22 experts who had been selected for round 1 to invite them to the second round. After three reminder emails, 22 experts answered the questions in round 2 . This response rate was acceptable regarding the Delphi studies in the literature. The experts had two weeks in each round to complete the questionnaire [115].

\section{Round 1}

The essential Survey tool was sent to the 45 experts as an online questionnaire; however, 22 people agreed to participate in this study in two or three rounds. Given the variety in the participants' backgrounds, they were informed about the project, research aims, several keywords, and the general framework. They were asked to score the importance of the indicators on an 11-item Likert scale (Additional file 1). Taking the SD below two more efficiently needs to define the 11-points Likertscale questionnaire [114].

A total of 111 indicators and 15 criteria were derived from the desk study. The criteria were introduced as: "1) personal characteristics, 2) behavioural attitude, 3) land use, 4) access, 5) physical form, 6) cityscape/city image, 7) public open spaces, 8) housing, 9) social environment, 
Table 1 The list of Dimensions, Criteria And Indicators with References from Desk study

\begin{tabular}{|c|c|c|c|}
\hline Dimensions & Criteria & Indicators & References \\
\hline \multirow[t]{20}{*}{ Personal characteristic } & \multirow{17}{*}{$\begin{array}{l}\text { Personal characteristic/ } \\
\text { determinants }\end{array}$} & age & [20-25] \\
\hline & & gender & \\
\hline & & Education & \\
\hline & & Ethnicity & \\
\hline & & Residential tenure & \\
\hline & & Marital status & \\
\hline & & Household size & \\
\hline & & Driving license & \\
\hline & & Employment/ paid work & \\
\hline & & Eating/drinking habitat & {$[25,26]$} \\
\hline & & Family support/ domestic care & {$[25,27]$} \\
\hline & & Self-care & {$[25,28]$} \\
\hline & & Self-promotion & {$[25,28]$} \\
\hline & & Mutual help/ & {$[25,28]$} \\
\hline & & Self-esteem & {$[25,28]$} \\
\hline & & Life satisfaction & {$[25,29]$} \\
\hline & & Travel behaviour & {$[25,30]$} \\
\hline & \multirow{3}{*}{$\begin{array}{l}\text { Behavioural attitude/ } \\
\text { determinants }\end{array}$} & Smoking & [29] \\
\hline & & Alcohol & {$[25,31]$} \\
\hline & & Length of activity & {$[25,31]$} \\
\hline \multirow[t]{23}{*}{ Place-related } & \multirow[t]{6}{*}{ Land- use } & Shopping services & {$[23,25,32-34]$} \\
\hline & & service proximity & {$[25,35]$} \\
\hline & & public facility & {$[2,23,25]$} \\
\hline & & mix use & {$[23,32,34,36-39]$} \\
\hline & & Facilities management & [40] \\
\hline & & sport recreation facility & {$[41,42]$} \\
\hline & \multirow[t]{7}{*}{ Access } & Connectivity & {$[3,34,43,44]$} \\
\hline & & Accessibility services & {$[22,23,25,38,44-52]$} \\
\hline & & Traffic condition & \\
\hline & & Pavement condition & \\
\hline & & Walkable Environment & $\begin{array}{l}{[3,20,23,32-34,38,39,41,43-45,49,50,} \\
52-66]\end{array}$ \\
\hline & & Mobility & {$[3,30,42,43,52,54,60,67-69]$} \\
\hline & & Transportation & {$[22,23,46,51,52,57,60,64,70]$} \\
\hline & \multirow[t]{7}{*}{ Physical form } & Up keeping & \\
\hline & & Abandon buildings & \\
\hline & & $\begin{array}{l}\text { Presence amenities/infrastructure } \\
\text { sufficiency }\end{array}$ & \\
\hline & & Urban Block size & {$[34,71,72]$} \\
\hline & & Safety & {$[20,22,23,32,38,49,57,64]$} \\
\hline & & Security & {$[22,32,33,35,43,44,46,73,74]$} \\
\hline & & green space & {$[3,43,44,75]$} \\
\hline & \multirow[t]{3}{*}{ Cityscape/City Image } & perceived distance & \\
\hline & & legibility & [53] \\
\hline & & Perceived Aesthetics & {$[3,20,23,34,36,38,49,64,73]$} \\
\hline
\end{tabular}


Table 1 The list of Dimensions, Criteria And Indicators with References from Desk study (Continued)

\begin{tabular}{|c|c|c|c|}
\hline Dimensions & Criteria & Indicators & References \\
\hline & & Natural scenery & {$[23,32]$} \\
\hline & Public open spaces & Street lighting & {$[23,43,51,76]$} \\
\hline & & Area open spaces ratio & [77] \\
\hline & & Recreation Public open spaces & [78] \\
\hline & & Quietness & \\
\hline & & cleanness & {$[3,34,44,64,73]$} \\
\hline & & maintenance & {$[44,53]$} \\
\hline & & Pollution & [50] \\
\hline & & Landscaping quality & {$[3,34,43,44,51,53]$} \\
\hline & Housing & Universal design & {$[37,57,79,80]$} \\
\hline & & Residential density & {$[32,37-39,81]$} \\
\hline & & Residential Care Facility & [59] \\
\hline & & Type of housing & [82-84] \\
\hline \multirow{24}{*}{$\begin{array}{l}\text { Socio-economic } \\
\text { environment }\end{array}$} & Social Environment & Life expectancy & [35] \\
\hline & & Quality life & {$[26,42,52,59,61,81,85]$} \\
\hline & & Social interaction/ community activities & {$[22,44,46,86,87]$} \\
\hline & & Happiness & [88] \\
\hline & & Social inclusion & {$[32,35,43,46,49,71,89]$} \\
\hline & & Social Inequalities & [58] \\
\hline & & Social Demography & {$[20,90]$} \\
\hline & & Social democracy & {$[32,91]$} \\
\hline & & Participation & {$[21,22,30,33,54,67,71,74,92-95]$} \\
\hline & & Social Support & {$[31,41,44,49]$} \\
\hline & & Education learning & [31] \\
\hline & & Social capital & [49] \\
\hline & Cultural Environment & Religious activity & {$[33,43,51,67,73,75]$} \\
\hline & & Cultural events & \\
\hline & & Sense place & \\
\hline & Economic Environment & healthcare services & {$[22,31,51,74]$} \\
\hline & & limited income & [31] \\
\hline & & insurance coverage & [31] \\
\hline & & Socio-economic status & {$[20,32]$} \\
\hline & & Affordable housing & [22] \\
\hline & & Car ownership & [32] \\
\hline & & Homeownership & {$[85]$} \\
\hline & & Household income & [25] \\
\hline & & Living situation & {$[25,32,59]$} \\
\hline \multirow[t]{4}{*}{ Governmental } & Good Governance & Effective collaboration & {$[79,96-102]$} \\
\hline & & Performance orientation & {$[47,59,62,101-103]$} \\
\hline & & governance & \\
\hline & & Equity & \\
\hline \multirow[t]{3}{*}{ Health } & Physical Health & Disability & {$[30,42,55]$} \\
\hline & & Public Health & {$[25,30,33,43,51,56,66,76]$} \\
\hline & & Incidence of disease & [25] \\
\hline
\end{tabular}


Table 1 The list of Dimensions, Criteria And Indicators with References from Desk study (Continued)

\begin{tabular}{|c|c|c|c|}
\hline Dimensions & Criteria & Indicators & References \\
\hline & & Pain feeling & [25] \\
\hline & & Functional ability & [25] \\
\hline & & Risk institutionalization & [25] \\
\hline & & Self-reported falls & {$[24,25]$} \\
\hline & & Self-reported health & [25] \\
\hline & & Physical activity & {$[25,33,74,81,85]$} \\
\hline & & Activities daily living & [25] \\
\hline & & Genetic factors & [25] \\
\hline & & BMI & {$[25,56]$} \\
\hline & & Sleep hygiene & [28] \\
\hline & & Personal hygiene & [28] \\
\hline & \multirow[t]{9}{*}{ Mental Health } & Depressive & \\
\hline & & Cognitive functioning & {$[25,30,51,54,76,81]$} \\
\hline & & Psychological distress & \\
\hline & & Psychological well-being & \\
\hline & & Anxiety & \\
\hline & & Anger & \\
\hline & & Restorative activity & \\
\hline & & Spiritual activity & \\
\hline & & Self-actualization & {$[43,104]$} \\
\hline & \multirow[t]{4}{*}{ Social Health } & Relation family & {$[30,32,59,105,106]$} \\
\hline & & Relation work & \\
\hline & & social life & \\
\hline & & sense community & {$[87,105]$} \\
\hline
\end{tabular}

10) cultural Environment, 11) economic environment, 12) good governance, 13) physical health, 14) mental health, and 15) social health. The ecological themes of Active Aging can be represented as the 5P model, which consists of person, processes, place, prime, and policy-making” [1].

The experts also added several indicators to our list through their answers to open-ended questions. These new items were included in the questionnaire of round 2 .

\section{Round 2}

Round 2 was conducted among those panellists who had participated in round 1 . The structure of the questionnaire resembled that of round 1 . The modified framework was presented to the participants along with a statistical summary (i.e., mean values) of the results of round 1. Besides, the questionnaires were customised for the participants to access their previous answers and the experts' items. Finally, the questionnaire of round 2, which consisted of 100 items, was administered to the experts. This feedback process was carried out to encourage the panellists to reconsider the ratings to reach a consensus.

\section{Data analysis}

The results of the questionnaires of both rounds were keyed in and analysed using the Statistical Package for Social Sciences (SPSS) version 22.0 for Windows. We mainly focused on the descriptive analysis of the data, particularly central tendency (means) and level of dispersion (SD). The 11 anchors of the Likert scale ranging from 1: "Not at all Important" or "Not at all suitable" to 11: "Extremely Important" or "Extremely suitable" were used to determine the 'importance' and 'suitability' of each attribute. Importance indicates how much the experts regarded the feature in question as essential for AA's assessment. Open-ended questions were included in line with Taylor and Judd's recommendation (1989) to collect additional information to clarify the problems at hand. The experts were also asked to make suggestions to enhance the framework and add further criteria and indicators not listed in the questionnaire. Based on the modifications resulting from the comments received in round 1 , the participants repeated their assessment in 


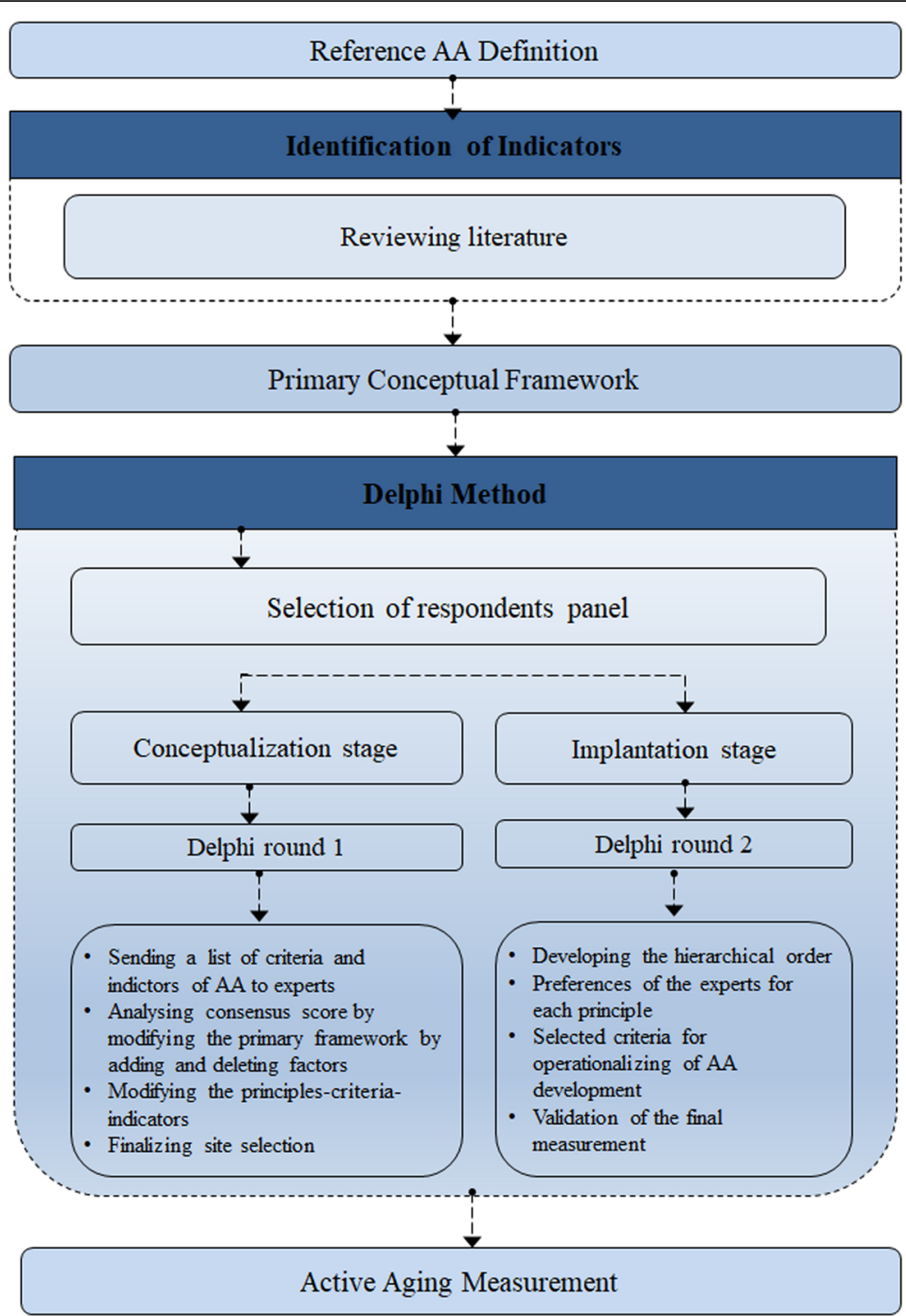

Fig. 2 The Research Process

round 2. As the two rounds proved sufficient for achieving a consensus that was confirmed by statistical analysis, further rounds were not needed.

\section{Results}

\section{Delphi panelists and participants response}

Due to the interdisciplinary nature of Active Aging, we tried to determine the participants' profiles by using a heterogeneous selection of experts. The 22 participants in this study were experts in urban design (23\%), architecture (13\%), urban planning (13\%), landscape architecture (13\%), gerontology (19\%), and geriatrics (19\%).

The participants were already familiar with different aspects of Active Aging and AAM from an ecological point of view. The participants were selected from locations as geographically diverse as Asia, Europe, America, and Australia to incorporate heterogeneous opinions into the new Active Aging measurement. This variety had a considerable effect on selecting indicators and enriched the new assessment tool due to the opinions' critical nature.

Moreover, Cronbach's $\alpha$ was measured to examine the reliability of the self-developed questionnaire (Supplementary File 1) and the internal consistency of opinion among the Delphi panellists. "To ensure the reliability of the data for further analysis, the study initially measured the validity of the Cronbach's $\alpha$ and SD to measure the level of agreement in each round" $[6,110]$. The results showed that the Cronbach's alpha was 0.71 in round 1 and 0.79 in round 2.

Open-ended questions in the first stage of Delphi with the addition and subtraction of some concepts are 
considered valid measurement tools, mostly since 22 people answered positively to the extracted indicators in two rounds of the Delphi technique.

\section{The Delphi survey results \\ Round 1}

In round 1, the experts scored the 15 criteria and 111 indicators in terms of five dimensions. Furthermore, 20 additional criteria were also suggested through the open-ended items in the questionnaire. The majority of the suggestions included modifying the definitions or labels of the existing indicators, proposing new indicators, and re-arranging the framework's indicators. For example, the term 'paid work' was suggested instead of 'limited work' and 'life scheme' instead of 'self-esteem.' The indicators that were added according to the suggestions include ICT use, art activities, having a pension, household expenditure, comfort, lifelong learning, leisure activities and recreational activities, living at least with one child, and functionality/indecency in activities.

Some other indicators were also suggested in different classifications. After the fundamental quantitative analysis, the reliability of the questionnaire was measured using Cronbach's alpha. The value was 0.98, which is higher than the minimum threshold of 0.7 and indicates high internal consistency and reliability.

In our quantitative analysis, we measured SD, mean values, and general agreement. The results are summarised in Table 2. Based on the results of round 1, the indicators with an SD greater than 2.5 and a mean less than six were eliminated. The indicators removed in this phase include ethnicity, residential tenure, household size, driving license, self-promotion, smoking, alcohol, facility management, social demography, social democracy, insurance coverage, homeownership, household income, living situation, performance orientation, risk institutionalisation, and genetic factors.

Finally, the items were reduced from 111 to 99 by eliminating 18 items (yellow line in Table 1), and ten new indicators (Green line in Table 2) were added to the questionnaire based on our qualitative analysis. The final questionnaire in round 2 contained 100 indicators and 15 criteria. Also, the questionnaire was slightly modified following the suggestions of some experts. For instance, self-esteem was moved to the dimension of psychological health.

\section{Round 2}

Table 3 presents the descriptive statistics (mean and SD) for the questionnaire completed by 22 experts in the second round. The results are indicative of a 51\% reduction in SD in round 2 of the Delphi survey. The indicators' mean value has increased compared to the first round, and there is a significant difference in specific agreement between the two rounds. Besides, Kendall's w indicates that the overall agreement's mean value has increased from 0.75 to 0.81 in the second round. It should be noted that Kendall's $\mathrm{w}$ lies in a range from 0 (no agreement) to 1 (complete agreement). The authors decided to finish the Delphi survey after the second round because the difference between the two rounds was less than $20 \%$, confirming a stable situation. Furthermore, most indicators reached a high level of a specific agreement, which is indicated by the value of Kendall's w that shows the difference between the means in the two rounds of the Delphi survey.

\section{Discussion}

We have developed an innovative measurement to imply the values of active aging characteristics based on the ecological model in both research or practice, as well as a self-rated and expert-based tool. Accordingly, the Active Aging Measurement in Urban Areas (AAMU) indicates the critical information provided by taking different levels of the environment, personal circumstances, and their relations into account in the elder's life and culture-specific approach. The substantial difference between this tool and previous studies arises from the understanding that before we can evaluate the individual aspect of active aging, we need to define the nature of active aging in the relationship between person and environment. This measurement can assess active aging at the individual, spatial, socio-economic, governance, and the elders' health levels. Also, this study was conducted the Delphi technique by applying 22 academic experts' views with different knowledge in active aging to emerge the consensus based on a multidisciplinary approach in urban areas. Applying the context-based approach to understand the elders' needs and preferences and considering the experts' point of views to meet the elderly need to promote active aging, could help to develop the holistic measures.

Our findings represent Active Aging as a notion that begins at an individual layer (person) and involves personal characteristics and behavioural attitudes, segments of the social or physical environment, and a policymaking environment that differentiated this novelty from other studies. These factors are closely interrelated and need to function in tandem to fulfil Active Aging in a particular social, cultural, and religious system [19].

Such conception builds upon an ecological model [2, 116 , 117] that focuses on the relations among the environmental levels of an aging person in the five dimensions while considering the micro (person), meso (process), and macro systems (place and policy-making) in terms of the health dimension), along with the vulnerable balance between individual competence and the environment in old age [19]. The nexus of cultural, social, 
Table 2 Descriptive Statistics (Round 1)

\begin{tabular}{|c|c|c|c|c|c|c|c|c|}
\hline Dimensions & Criteria & Indicators & $\mathrm{N}$ & Minimum & Maximum & Mean & $\begin{array}{l}\text { Std. } \\
\text { Deviation }\end{array}$ & $\begin{array}{l}\text { Rate of } \\
\text { Agreement }\end{array}$ \\
\hline \multirow{20}{*}{$\begin{array}{l}\text { Personal } \\
\text { characteristic }\end{array}$} & \multirow{17}{*}{$\begin{array}{l}\text { Personal characteristic } \\
\text { /determinants }\end{array}$} & age & 23 & 0 & 11 & 8.00 & 2.000 & 0.727 \\
\hline & & gender & 23 & 0 & 11 & 7.00 & 2.000 & 0.636 \\
\hline & & Education & 23 & 0 & 11 & 6.00 & 2.000 & 0.545 \\
\hline & & Ethnicity & 23 & 0 & 11 & 5.05 & 3.000 & 0.459 \\
\hline & & Residential tenure & 23 & 0 & 10 & 5.00 & 3.000 & 0.455 \\
\hline & & Marital status & 23 & 0 & 11 & 7.00 & 2.500 & 0.636 \\
\hline & & Household size & 23 & 0 & 11 & 5.00 & 3.000 & 0.455 \\
\hline & & Driving license & 23 & 0 & 11 & 6.00 & 3.000 & 0.545 \\
\hline & & Employment/ paid work & 23 & 0 & 11 & 7.00 & 2.500 & 0.636 \\
\hline & & Eating/drinking habitat & 23 & 1 & 11 & 7.00 & 2.500 & 0.636 \\
\hline & & Family support/ domestic care & 23 & 5 & 11 & 9.00 & 1.000 & 0.818 \\
\hline & & Self-care & 23 & 0 & 11 & 7.00 & 2.500 & 0.636 \\
\hline & & Self-promotion & 23 & 0 & 11 & 6.00 & 3.000 & 0.545 \\
\hline & & Mutual help/ & 23 & 0 & 11 & 6.00 & 2.000 & 0.545 \\
\hline & & Self esteem & 23 & 0 & 11 & 7.00 & 2.000 & 0.636 \\
\hline & & Life satisfaction & 23 & 0 & 11 & 7.00 & 2.000 & 0.636 \\
\hline & & Travel behavior & 23 & 0 & 11 & 7.00 & 2.000 & 0.636 \\
\hline & \multirow{3}{*}{$\begin{array}{l}\text { Behavioural attitude/ } \\
\text { determinants }\end{array}$} & Smoking & 23 & 0 & 11 & 6.00 & 3.000 & 0.545 \\
\hline & & Alcohol & 23 & 0 & 11 & 6.00 & 3.000 & 0.545 \\
\hline & & Length of activity & 23 & 5 & 11 & 9.00 & 1.000 & 0.818 \\
\hline \multirow[t]{23}{*}{ Place-related } & \multirow[t]{6}{*}{ Land- use } & Shopping services & 23 & 0 & 11 & 7.00 & 2.000 & 0.636 \\
\hline & & service proximity & 23 & 0 & 11 & 7.00 & 2.000 & 0.636 \\
\hline & & public facility & 23 & 1 & 11 & 7.00 & 2.000 & 0.636 \\
\hline & & mix use & 23 & 0 & 11 & 6.00 & 2.500 & 0.545 \\
\hline & & Facilities management & 23 & 0 & 11 & 5.00 & 3.000 & 0.455 \\
\hline & & sport recreation facility & 23 & 5 & 11 & 8.00 & 2.500 & 0.727 \\
\hline & \multirow[t]{7}{*}{ Access } & Connectivity & 23 & 0 & 11 & 8.09 & 2.000 & 0.735 \\
\hline & & Accessibility services & 23 & 0 & 11 & 7.00 & 2.000 & 0.636 \\
\hline & & Traffic condition & 23 & 0 & 11 & 7.00 & 2.000 & 0.636 \\
\hline & & Pavement condition & 23 & 2 & 11 & 8.09 & 2.000 & 0.735 \\
\hline & & Walkable Environment & 23 & 1 & 11 & 8.00 & 2.000 & 0.727 \\
\hline & & Mobility & 23 & 0 & 11 & 7.00 & 2.500 & 0.636 \\
\hline & & Transportation & 23 & 1 & 11 & 7.00 & 2.000 & 0.636 \\
\hline & \multirow[t]{7}{*}{ Physical form } & Up keeping & 23 & 5 & 11 & 7.00 & 1.000 & 0.636 \\
\hline & & Abandon buildings & 23 & 0 & 11 & 7.00 & 2.000 & 0.636 \\
\hline & & $\begin{array}{l}\text { Presence amenities/ } \\
\text { infrastructure sufficiency }\end{array}$ & 23 & 5 & 11 & 8.00 & 1.000 & 0.727 \\
\hline & & Urban Block size & 23 & 0 & 11 & 7.00 & 2.000 & 0.636 \\
\hline & & Safety & 23 & 0 & 11 & 7.00 & 2.000 & 0.636 \\
\hline & & Security & 23 & 2 & 11 & 8.00 & 2.000 & 0.727 \\
\hline & & green space & 23 & 3 & 11 & 8.00 & 2.000 & 0.727 \\
\hline & \multirow[t]{3}{*}{ Cityscape/City Image } & perceived distance & 23 & 4 & 11 & 8.00 & 2.000 & 0.727 \\
\hline & & legibility & 23 & 0 & 11 & 7.00 & 2.000 & 0.636 \\
\hline & & Perceived Aesthetics & 23 & 2 & 10 & 7.00 & 2.000 & 0.636 \\
\hline
\end{tabular}


Table 2 Descriptive Statistics (Round 1) (Continued)

\begin{tabular}{|c|c|c|c|c|c|c|c|c|}
\hline Dimensions & Criteria & Indicators & $\mathrm{N}$ & Minimum & Maximum & Mean & $\begin{array}{l}\text { Std. } \\
\text { Deviation }\end{array}$ & $\begin{array}{l}\text { Rate of } \\
\text { Agreement }\end{array}$ \\
\hline & & Natural scenery & 23 & 2 & 11 & 8.00 & 2.000 & 0.727 \\
\hline & Public open spaces & Street lighting & 23 & 0 & 11 & 7.00 & 2.000 & 0.636 \\
\hline & & Area open spaces ratio & 23 & 0 & 11 & 7.05 & 2.000 & 0.641 \\
\hline & & Recreation Public open spaces & 23 & 2 & 11 & 7.00 & 2.000 & 0.636 \\
\hline & & Quietness & 23 & 0 & 11 & 7.00 & 2.000 & 0.636 \\
\hline & & cleanness & 23 & 2 & 11 & 8.00 & 2.000 & 0.727 \\
\hline & & maintenance & 23 & 1 & 11 & 7.00 & 2.000 & 0.636 \\
\hline & & Pollution & 23 & 1 & 11 & 8.09 & 2.000 & 0.735 \\
\hline & & Landscaping quality & 23 & 1 & 11 & 7.00 & 2.000 & 0.636 \\
\hline & Housing & Universal design & 23 & 0 & 11 & 6.00 & 2.500 & 0.545 \\
\hline & & Residential density & 23 & 0 & 11 & 6.00 & 2.500 & 0.545 \\
\hline & & Residential Care Facility & 23 & 0 & 11 & 7.00 & 2.500 & 0.636 \\
\hline & & Type of housing & 23 & 0 & 11 & 7.00 & 2.000 & 0.636 \\
\hline \multirow{24}{*}{$\begin{array}{l}\text { Socio-economic } \\
\text { environment }\end{array}$} & Social Environment & Life expectancy & 23 & 0 & 11 & 7.00 & 2.500 & 0.636 \\
\hline & & Quality life & 23 & 0 & 11 & 8.00 & 2.500 & 0.727 \\
\hline & & $\begin{array}{l}\text { Social interaction/ community } \\
\text { activities }\end{array}$ & 23 & 3 & 11 & 9.09 & 2.000 & 0.826 \\
\hline & & Happiness & 23 & 1 & 11 & 7.00 & 2.000 & 0.636 \\
\hline & & Social inclusion & 23 & 1 & 11 & 8.00 & 2.000 & 0.727 \\
\hline & & Social Inequalities & 23 & 2 & 11 & 6.00 & 2.000 & 0.545 \\
\hline & & Social Demography & 23 & 0 & 11 & 6.00 & 3.000 & 0.545 \\
\hline & & Social democracy & 23 & 0 & 11 & 7.05 & 3.000 & 0.641 \\
\hline & & Participation & 23 & 2 & 11 & 7.00 & 2.000 & 0.636 \\
\hline & & Social Support & 23 & 2 & 11 & 8.00 & 2.000 & 0.727 \\
\hline & & Education learning & 23 & 2 & 11 & 7.00 & 2.000 & 0.636 \\
\hline & & Social capital & 23 & 1 & 11 & 7.00 & 2.000 & 0.636 \\
\hline & Cultural Environment & Religious activity & 23 & 0 & 11 & 8.05 & 2.000 & 0.732 \\
\hline & & Cultural events & 23 & 0 & 11 & 7.00 & 2.000 & 0.636 \\
\hline & & Sense place & 23 & 1 & 11 & 7.00 & 2.500 & 0.636 \\
\hline & Economic Environment & healthcare services & 23 & 1 & 11 & 8.05 & 2.000 & 0.732 \\
\hline & & limited income & 23 & 0 & 11 & 7.00 & 2.500 & 0.636 \\
\hline & & insurance coverage & 23 & 0 & 11 & 7.00 & 3.000 & 0.636 \\
\hline & & Socioeconomic statues & 23 & 0 & 11 & 7.00 & 2.500 & 0.636 \\
\hline & & Affordable housing & 23 & 1 & 11 & 7.00 & 2.000 & 0.636 \\
\hline & & Car ownership & 23 & 0 & 11 & 6.00 & 2.000 & 0.545 \\
\hline & & Homeownership & 23 & 0 & 11 & 7.00 & 3.000 & 0.636 \\
\hline & & Household income & 23 & 0 & 11 & 6.00 & 3.000 & 0.545 \\
\hline & & Living situation & 23 & 0 & 11 & 6.00 & 3.013 & 0.545 \\
\hline \multirow[t]{4}{*}{ Governmental } & Good Governance & Effective collaboration & 23 & 2 & 11 & 8.00 & 2.087 & 0.727 \\
\hline & & Performance orientation & 23 & 0 & 11 & 6.00 & 3.000 & 0.545 \\
\hline & & governance & 23 & 0 & 11 & 6.00 & 2.500 & 0.545 \\
\hline & & Equity & 23 & 0 & 11 & 7.00 & 2.500 & 0.636 \\
\hline \multirow[t]{2}{*}{ Health } & Physical Health & Disability & 23 & 0 & 11 & 8.00 & 2.000 & 0.727 \\
\hline & & Public Health & 23 & 0 & 11 & 8.00 & 2.500 & 0.727 \\
\hline
\end{tabular}


Table 2 Descriptive Statistics (Round 1) (Continued)

\begin{tabular}{|c|c|c|c|c|c|c|c|c|}
\hline Dimensions & Criteria & Indicators & $\mathrm{N}$ & Minimum & Maximum & Mean & $\begin{array}{l}\text { Std. } \\
\text { Deviation }\end{array}$ & $\begin{array}{l}\text { Rate of } \\
\text { Agreement }\end{array}$ \\
\hline & & Incidence disease & 23 & 0 & 11 & 8.00 & 2.000 & 0.727 \\
\hline & & Pain feeling & 23 & 2 & 11 & 8.00 & 2.000 & 0.727 \\
\hline & & Functional ability & 23 & 0 & 11 & 8.00 & 2.000 & 0.727 \\
\hline & & Risk institutionalization & 23 & 0 & 11 & 6.00 & 3.000 & 0.545 \\
\hline & & Self-reported falls & 23 & 2 & 11 & 7.00 & 2.000 & 0.636 \\
\hline & & Self-reported health & 23 & 2 & 11 & 7.00 & 2.000 & 0.636 \\
\hline & & Physical activity & 23 & 0 & 11 & 7.00 & 2.500 & 0.636 \\
\hline & & Activities daily living & 23 & 0 & 11 & 8.00 & 2.000 & 0.727 \\
\hline & & Genetic factors & 23 & 1 & 11 & 7.00 & 3.000 & 0.636 \\
\hline & & BMI & 23 & 1 & 11 & 7.00 & 2.000 & 0.636 \\
\hline & & Sleep hygiene & 23 & 1 & 11 & 7.00 & 2.000 & 0.636 \\
\hline & & Personal hygiene & 23 & 1 & 11 & 6.00 & 2.000 & 0.545 \\
\hline & \multirow[t]{9}{*}{ Mental Health } & Depressive & 23 & 1 & 11 & 8.05 & 2.000 & 0.732 \\
\hline & & Cognitive functioning & 23 & 7 & 11 & 9.09 & 1.000 & 0.826 \\
\hline & & Psychological distress & 23 & 1 & 11 & 8.00 & 2.000 & 0.727 \\
\hline & & Psychological wellbeing & 23 & 3 & 11 & 8.00 & 2.000 & 0.727 \\
\hline & & Anxiety & 23 & 0 & 11 & 7.00 & 2.500 & 0.636 \\
\hline & & Anger & 23 & 1 & 11 & 7.00 & 2.000 & 0.636 \\
\hline & & Restorative activity & 23 & 1 & 11 & 8.00 & 2.000 & 0.727 \\
\hline & & Spiritual activity & 23 & 0 & 11 & 7.00 & 2.000 & 0.636 \\
\hline & & Self-actualization & 23 & 0 & 11 & 7.00 & 2.000 & 0.636 \\
\hline & \multirow[t]{4}{*}{ Social Health } & Relation family & 23 & 0 & 11 & 8.00 & 2.500 & 0.727 \\
\hline & & Relation work & 23 & 0 & 11 & 8.00 & 2.500 & 0.727 \\
\hline & & social life & 23 & 1 & 11 & 8.00 & 2.000 & 0.727 \\
\hline & & sense community & 23 & 1 & 11 & 8.00 & 2.000 & 0.727 \\
\hline
\end{tabular}

and economic factors play a significant role in Active Aging and has a strong effect on social, incredibly emotional relationships in old age [118].

In this study, we indicated that lifelong learning is another essential factor influencing the elderly's well-being. Given that productive activities could be conceived as a kind of social participation, merely caring for older people did not prove to be an adequate solution in this model. A possible explanation is that long-term care of older people who are ill or dependent may negatively affect the caregivers' psychological well-being [119] or physical and mental health [119].

Furthermore, life satisfaction, which depends upon an individual's cognitive evaluation of one's life, may affect policy-making strategies. This satisfaction is influenced by an older adult's perception of the quality of life and his or her private experiences [118]. Moreover, the way older people obtain life satisfaction may also be quite different from younger adults, e.g., by preferring emotionally close relationships to other social activities [120]. Nevertheless, lower life satisfaction has been found in specific cases, such as reduced self-care capacity or older caregivers. The results are affected by self-care capacity, the level of self-reported health, and dissatisfaction with social relationships, which are all based on the older adult's perceptions [118]. Besides, the significance of ICT has also been indicated as a relatively new variable that forms active aging [119]. Currently, ICT is widely regarded as a predictor variable for Active Aging, improving older people's well-being and increasing their engagement with life [119].

The cultural and social notion of Active Aging, with its contextual nature [121], has arisen out of environmental contexts' diversity to clarify how a person reacts to and interacts with their environment $[117,122]$. As suggested by the findings of our study, Active Aging results from personal, socio-cultural, and governance environments that are directly associated with the indicators of individual, environmental, social, economic, institutional, health-related factors.

Besides, this study identified a set of indicators for assessing those characteristics of quality of place that 
Table 3 Descriptive Statistics (Round 2)

\begin{tabular}{|c|c|c|c|c|c|c|c|c|}
\hline Dimensions & Criteria & Indicators & $\mathbf{N}$ & Minimum & Maximum & Mean & $\begin{array}{l}\text { Std. } \\
\text { Deviation }\end{array}$ & $\begin{array}{l}\text { Rate of } \\
\text { Agreement }\end{array}$ \\
\hline \multirow[t]{14}{*}{ Personal characteristic } & \multirow{12}{*}{$\begin{array}{l}\text { Personal characteristic } \\
\text { /determinants }\end{array}$} & age & 23 & 0 & 11 & 8.50 & 2.00 & 0.773 \\
\hline & & gender & 23 & 0 & 11 & 8.00 & 2.00 & 0.727 \\
\hline & & Education & 23 & 0 & 11 & 6.50 & 2.00 & 0.591 \\
\hline & & Marital status & 23 & 0 & 11 & 7.00 & 2.00 & 0.636 \\
\hline & & Employment/ paid work & 23 & 0 & 10 & 7.50 & 2.00 & 0.682 \\
\hline & & Eating/drinking habitat & 23 & 0 & 11 & 8.00 & 2.00 & 0.727 \\
\hline & & Family support/ domestic care & 23 & 0 & 11 & 9.00 & 1.00 & 0.818 \\
\hline & & Self-care & 23 & 0 & 11 & 8.00 & 2.00 & 0.727 \\
\hline & & Mutual help/ Having a Partner & 23 & 0 & 11 & 8.00 & 2.00 & 0.727 \\
\hline & & Life satisfaction & 23 & 1 & 11 & 7.50 & 2.00 & 0.682 \\
\hline & & Travel behavior & 23 & 5 & 11 & 7.50 & 2.00 & 0.682 \\
\hline & & living at least with one child & 23 & 0 & 11 & 6.00 & 2.00 & 0.545 \\
\hline & \multirow[t]{2}{*}{$\begin{array}{l}\text { Behavioural attitude/ } \\
\text { determinants }\end{array}$} & $\begin{array}{l}\text { Functionality/ indecency in } \\
\text { activities }\end{array}$ & 23 & 0 & 11 & 6.00 & 2.00 & 0.545 \\
\hline & & Length of activity & 23 & 0 & 11 & 9.00 & 1.00 & 0.818 \\
\hline \multirow[t]{28}{*}{ Place-related } & \multirow[t]{5}{*}{ Land- use } & Shopping services & 23 & 0 & 11 & 7.50 & 2.00 & 0.682 \\
\hline & & service proximity & 23 & 0 & 11 & 7.00 & 2.00 & 0.636 \\
\hline & & public facility & 23 & 0 & 11 & 7.00 & 2.00 & 0.636 \\
\hline & & mix use & 23 & 0 & 11 & 8.00 & 2.00 & 0.727 \\
\hline & & sport recreation facility & 23 & 0 & 11 & 8.50 & 2.00 & 0.773 \\
\hline & \multirow[t]{7}{*}{ Access } & Connectivity & 23 & 0 & 11 & 8.09 & 2.00 & 0.735 \\
\hline & & Accessibility services & 23 & 0 & 11 & 7.50 & 2.00 & 0.682 \\
\hline & & Traffic condition & 23 & 5 & 11 & 7.50 & 2.00 & 0.682 \\
\hline & & Pavement condition & 23 & 0 & 11 & 8.09 & 2.00 & 0.735 \\
\hline & & Walkable Environment & 23 & 0 & 11 & 8.00 & 2.00 & 0.727 \\
\hline & & Mobility & 23 & 1 & 11 & 7.50 & 2.00 & 0.682 \\
\hline & & Transportation & 23 & 0 & 11 & 8.00 & 2.00 & 0.727 \\
\hline & \multirow[t]{7}{*}{ Physical form } & Up keeping & 23 & 0 & 11 & 8.00 & 1.00 & 0.727 \\
\hline & & Abandon buildings & 23 & 5 & 11 & 7.00 & 2.00 & 0.636 \\
\hline & & $\begin{array}{l}\text { Presence amenities/ } \\
\text { Infrastructure sufficiency }\end{array}$ & 23 & 0 & 11 & 8.00 & 1.00 & 0.727 \\
\hline & & Urban Block size & 23 & 0 & 11 & 7.50 & 2.00 & 0.682 \\
\hline & & Safety & 23 & 0 & 11 & 7.50 & 2.00 & 0.682 \\
\hline & & Security & 23 & 2 & 11 & 8.00 & 2.00 & 0.727 \\
\hline & & green space & 23 & 1 & 11 & 8.00 & 2.00 & 0.727 \\
\hline & \multirow[t]{4}{*}{ Cityscape/City Image } & perceived distance & 23 & 0 & 11 & 8.00 & 2.00 & 0.727 \\
\hline & & legibility & 23 & 1 & 11 & 8.00 & 2.00 & 0.727 \\
\hline & & Perceived Aesthetics & 23 & 5 & 11 & 7.00 & 2.00 & 0.636 \\
\hline & & Natural scenery & 23 & 0 & 11 & 8.00 & 2.00 & 0.727 \\
\hline & \multirow[t]{5}{*}{ Public open spaces } & Street lighting & 23 & 5 & 11 & 7.00 & 2.00 & 0.636 \\
\hline & & Area open spaces ratio & 23 & 0 & 11 & 8.00 & 2.00 & 0.727 \\
\hline & & Recreation Public open spaces & 23 & 0 & 11 & 7.00 & 2.00 & 0.636 \\
\hline & & Quietness & 23 & 2 & 11 & 7.50 & 2.00 & 0.682 \\
\hline & & cleanness & 23 & 3 & 11 & 8.00 & 2.00 & 0.727 \\
\hline
\end{tabular}


Table 3 Descriptive Statistics (Round 2) (Continued)

\begin{tabular}{|c|c|c|c|c|c|c|c|c|}
\hline Dimensions & Criteria & Indicators & $\mathbf{N}$ & Minimum & Maximum & Mean & $\begin{array}{l}\text { Std. } \\
\text { Deviation }\end{array}$ & $\begin{array}{l}\text { Rate of } \\
\text { Agreement }\end{array}$ \\
\hline & & maintenance & 23 & 4 & 11 & 7.50 & 2.00 & 0.682 \\
\hline & & Pollution & 23 & 0 & 11 & 8.09 & 2.00 & 0.735 \\
\hline & & Landscaping quality & 23 & 2 & 10 & 7.00 & 2.00 & 0.636 \\
\hline & Housing & Universal design & 23 & 2 & 11 & 6.00 & 2.50 & 0.545 \\
\hline & & Residential density & 23 & 0 & 11 & 6.00 & 2.00 & 0.545 \\
\hline & & Residential Care Facility & 23 & 0 & 11 & 8.00 & 2.00 & 0.727 \\
\hline & & Type of housing & 23 & 2 & 11 & 7.00 & 2.00 & 0.636 \\
\hline \multirow{19}{*}{$\begin{array}{l}\text { Socio-economic } \\
\text { environment }\end{array}$} & Social Environment & Life expectancy & 23 & 0 & 11 & 7.00 & 2.00 & 0.636 \\
\hline & & Quality life & 23 & 2 & 11 & 8.00 & 2.00 & 0.727 \\
\hline & & $\begin{array}{l}\text { Social interaction/ community } \\
\text { activities }\end{array}$ & 23 & 1 & 11 & 9.09 & 2.00 & 0.826 \\
\hline & & Happiness & 23 & 1 & 11 & 7.50 & 2.00 & 0.682 \\
\hline & & Social inclusion & 23 & 1 & 11 & 8.00 & 2.00 & 0.727 \\
\hline & & Social Inequalities & 23 & 0 & 11 & 6.00 & 2.00 & 0.545 \\
\hline & & Social Participation & 23 & 0 & 11 & 7.00 & 2.00 & 0.636 \\
\hline & & Social Support & 23 & 0 & 11 & 8.00 & 2.00 & 0.727 \\
\hline & & lifelong learning & 23 & 0 & 11 & 7.00 & 2.00 & 0.636 \\
\hline & & Social capital & 23 & 0 & 11 & 7.50 & 2.00 & 0.682 \\
\hline & & Religious activity & 23 & 0 & 11 & 8.05 & 2.00 & 0.732 \\
\hline & & Cultural events/ activities & 23 & 3 & 11 & 7.50 & 2.00 & 0.682 \\
\hline & & Sense of place & 23 & 1 & 11 & 7.00 & 2.00 & 0.636 \\
\hline & Economic Environment & health care services & 23 & 1 & 11 & 8.05 & 2.00 & 0.732 \\
\hline & & limited income/ paid work & 23 & 2 & 11 & 7.00 & 2.00 & 0.636 \\
\hline & & Having pension & 23 & 0 & 11 & 7.00 & 2.00 & 0.636 \\
\hline & & Household expenditure & 23 & 0 & 11 & 7.50 & 2.00 & 0.682 \\
\hline & & ICT use & 23 & 2 & 11 & 7.00 & 2.00 & 0.636 \\
\hline & & Affordable housing & 23 & 2 & 11 & 7.50 & 2.00 & 0.682 \\
\hline \multirow[t]{3}{*}{ Governmental } & Good Governance & Effective collaboration & 23 & 2 & 11 & 8.00 & 2.00 & 0.727 \\
\hline & & Good governance & 23 & 1 & 11 & 7.00 & 2.00 & 0.636 \\
\hline & & Equity & 23 & 0 & 11 & 7.50 & 2.00 & 0.682 \\
\hline \multirow[t]{12}{*}{ Health } & Physical Health & $\begin{array}{l}\text { Disability. At least one ADL } \\
\text { Disability }\end{array}$ & 23 & 0 & 11 & 8.00 & 2.00 & 0.727 \\
\hline & & Public Health & 23 & 2 & 11 & 8.50 & 2.00 & 0.773 \\
\hline & & Incidence disease & 23 & 2 & 11 & 8.00 & 2.00 & 0.727 \\
\hline & & Pain feeling & 23 & 1 & 11 & 8.50 & 2.00 & 0.773 \\
\hline & & Functional-ability & 23 & 1 & 11 & 8.00 & 2.00 & 0.727 \\
\hline & & Self-reported falls & 23 & 0 & 11 & 8.00 & 2.00 & 0.727 \\
\hline & & Self-reported health & 23 & 0 & 11 & 7.50 & 2.00 & 0.682 \\
\hline & & Art activities & 23 & 0 & 11 & 7.00 & 2.00 & 0.636 \\
\hline & & $\begin{array}{l}\text { Leisure activities. Recreational } \\
\text { activities }\end{array}$ & 23 & 0 & 11 & 7.00 & 2.00 & 0.636 \\
\hline & & Physical activity & 23 & 1 & 11 & 7.00 & 2.00 & 0.636 \\
\hline & & $\begin{array}{l}\text { Activities daily living Level } \\
\text { (ADL) }\end{array}$ & 23 & 0 & 11 & 8.00 & 2.00 & 0.727 \\
\hline & & BMl & 23 & 0 & 11 & 7.50 & 2.00 & 0.682 \\
\hline
\end{tabular}


Table 3 Descriptive Statistics (Round 2) (Continued)

\begin{tabular}{|c|c|c|c|c|c|c|c|c|}
\hline Dimensions & Criteria & Indicators & $\mathbf{N}$ & Minimum & Maximum & Mean & $\begin{array}{l}\text { Std. } \\
\text { Deviation }\end{array}$ & $\begin{array}{l}\text { Rate of } \\
\text { Agreement }\end{array}$ \\
\hline & & Sleep hygiene & 23 & 0 & 11 & 7.00 & 2.00 & 0.636 \\
\hline & & Personal hygiene & 23 & 0 & 11 & 7.00 & 2.00 & 0.636 \\
\hline & \multirow[t]{10}{*}{ Mental Health } & Depression & 23 & 2 & 11 & 8.05 & 2.00 & 0.732 \\
\hline & & Cognitive functioning & 23 & 0 & 11 & 9.00 & 1.00 & 0.818 \\
\hline & & Psychological distress & 23 & 0 & 11 & 8.00 & 2.00 & 0.727 \\
\hline & & Psychological wellbeing & 23 & 0 & 11 & 8.00 & 2.00 & 0.727 \\
\hline & & Anxiety & 23 & 0 & 11 & 7.00 & 2.00 & 0.636 \\
\hline & & Anger & 23 & 0 & 11 & 7.50 & 2.00 & 0.682 \\
\hline & & Restorative activity & 23 & 0 & 11 & 8.00 & 2.00 & 0.727 \\
\hline & & Spiritual activity & 23 & 2 & 11 & 7.50 & 2.00 & 0.682 \\
\hline & & Self-esteem. Life scheme & 23 & 0 & 11 & 7.50 & 2.00 & 0.682 \\
\hline & & Self-efficacy & 23 & 0 & 11 & 7.00 & 2.00 & 0.636 \\
\hline & \multirow[t]{4}{*}{ Social Health } & Relation in family & 23 & 2 & 11 & 8.00 & 2.00 & 0.727 \\
\hline & & Relation in work & 23 & 2 & 11 & 8.00 & 2.00 & 0.727 \\
\hline & & social life & 23 & 0 & 11 & 8.00 & 2.00 & 0.727 \\
\hline & & sense of community & 23 & 0 & 11 & 8.00 & 2.00 & 0.727 \\
\hline
\end{tabular}

might contribute to Active Aging. These include measures of land use characteristics (deprivation or poverty in an area and neighbourhood degradation), physical form (neighbourhood degradation, accessibility to services and facilities, accessibility of public green space, walkability or pedestrian-friendliness, and housing type), security against perceived crime and anti-social behaviour, traffic safety, quality of public spaces, aesthetic aspects of architecture, landscape (lighting and furniture), pedestrian-friendly features, availability of sitting facilities (e.g., benches) and restrooms (toilets in public open spaces), hazards for pedestrians(sidewalks), home and environmental adaptations, climatic comfort, topography, and other desirable physical attributes like trees and green areas which promote a sense of support resilience and well-being [19].

\section{Limitations}

This study faced the following limitations. The limitation is related to the reliability and validity of how expertise area categories were determined to select and invite the expert group. While statistical analyses and the literature generally support our findings, different experts from other areas might have provided different inputs to alter the study results. There were also inherent limitations in this study. 1) The findings from our Delphi survey must be validated by cross-sectional studies to verify the causal relationships among the variables. Of course, our assessment tool builds upon the knowledge provided by a wide range of agents (i.e., policy-makers, researchers, and the elderly). It may be an acceptable representation of the various elements of Active Aging discussed in the literature. 2) As the data concerning most of the variables were collected and assessed by self-reporting, subjective perceptions might have affected the results. Moreover, our sample was culturally homogeneous; therefore, further studies are required to validate the developed assessment tool in various cultural contexts.

Due to the different environments in urban and rural settlements, these environments have varied in economic, institutional, and sociodemographic structures in local Communities to create different lifestyles, needs, and expectations in the elderly. Therefore, to meet the needs and promote active aging, the developed measurement might be dissimilar in the elders' lives, especially in the live hood and living costs. SO, this study is limited to develop a measurement tool for urban communities.

\section{Strengths}

As discussed, the elderly's capabilities. Thus, our proposed instrument seeks to offer clear guidance to policymakers, which conforms well to older adults, experts, and local authorities' opinions. The characteristic of this study is the most practical nature and real-world implications.

An expert-based and self-rated assessment tool was developed to measure Active Aging on an individual/environmental scale (micro, meso, and macro-level). Another contribution is the conception of Active Aging, which has its roots in the literature (through the notion of healthy and productive Aging) and involves a 
remarkably more extensive range of activities. Besides, it regards people with disabilities as active agers [123]. According to our findings, which are based on the ideas of policy-makers, researchers, and the elderly, Active Aging can be measured at five levels. We can argue that Active Aging is a higher-order construct consisting of five categories: personal, place-based, socio-economic, governance, and health-related indicators.

\section{Conclusion}

The present researchers have developed the active aging measure for urban settlements (AAMU), which was can be used both by policy-makers and as an informal selfreported statement among the elderly. AAM's results in the elderly's residential environmental communities can improve policy-making to address urban design to sustain an active, healthy life among older people in urban environments.

\section{Supplementary Information}

The online version contains supplementary material available at https://doi. org/10.1186/s12889-020-10036-5.

Additional file 1. Questionnaire for Measuring Active Aging. The online Questionnaire in the first round of Delphi.

\section{Abbreviations}

AAM: Active Aging Measurement; WHO: World Health Organization; AA: Active Aging; AAl: Active Aging Index

\section{Acknowledgments}

Authors wish to express their gratitude to respected adamic staff who participated in all panels for this study.

\section{Authors' contributions \\ P.K.M and H.R.B designed the scoping review and conducted the searches. $A L$ and PR made substantial contributions to the review's conception to extract the themes and subthemes by reviewing all the analysis phase materials. AL and PR have done the two rounds of the Delphi study. PR has sent the online questionnaires to Delphi Panelists. AL and PR have analysed a statistical survey and drafted the manuscript with editorial and content input from all other authors. All authors have read and approved the final version of the paper.}

\section{Funding}

The authors received no financial support for this research study.

\section{Availability of data and materials}

The datasets used and/or analysed during the current study available from the corresponding author on reasonable request.

\section{Ethics approval and consent to participate}

This research was approved by the Iran University of Medical Sciences Ethical Review Board (Ethics Code Number; IR.IUMS.REC.1397.148) for the conduct of this research, and participants were contacted via telephone and consented verbally.

The Iran University of Medical Sciences approved the implied consent procedure, wherein verbal consent was implied upon beginning the survey.

\section{Consent for publication}

Not applicable.

\section{Competing interests}

The authors declare that they have no competing interests.

\section{Author details}

${ }^{1}$ Faculty of Architecture and Urban Planning, Shahid Beheshti University, Tehran 1983963113, Iran. ${ }^{2}$ Faculty of Architecture and Urban Planning, Khalij-e- Fars University, Bushehr, Iran. ${ }^{3}$ Ageing Clinical \& Experimental Research Team, Institute of Applied Health Sciences, University of Aberdeen, Aberdeen, UK. ${ }^{4}$ Department of Epidemiology, School of Public Health, Iran University of Medical Sciences, Tehran, Iran.

Received: 31 August 2020 Accepted: 9 December 2020

Published online: 03 January 2021

\section{References}

1. Rodrigues R, Hofmarcher MM, Leichsenring K, Winkelmann J. Active and healthy ageing for better long-term care: a fresh look at innovative practice examples. Vienna: AUT Eur Comm; 2013.

2. Ko P-C, Jean Yeung W-J. An ecological framework for active aging in China. J Aging Health. 2018;30:1642-76. https://doi.org/10.1177/ 0898264318795564.

3. WHO. Active ageing: A policy framework. 2002.

4. Lemon BW, Bengtson VL, Peterson JA. An exploration of the activity theory of aging: activity types and life satisfaction among in-movers to a retirement community. J Gerontol. 1972;27:511-23.

5. Lim EZK, Thompson CL. Measuring active ageing among older adults in Singapore. Ageing Soc. 2016;36:1853-69. https://doi.org/10.1017/ S0144686X15001312.

6. Davey J, Glasgow K. Positive ageing: a critical analysis. Policy Q. 2006;2(4).

7. Walker A. Active ageing: Realising its potential. Australas J Ageing. 2015; 34:2-8.

8. Arifin EN, Braun $\mathrm{KL}$, Hogervorst E. Three pillars of active ageing in Indonesia. Asian Popul Stud. 2012;8:207-30.

9. Boudiny K. 'Active ageing': from empty rhetoric to effective policy tool. Ageing Soc. 2013;33:1077-98.

10. Perales J, Martin S, Ayuso-Mateos JL, et al. Factors associated with active aging in Finland, Poland, and Spain. Int Psychogeriatrics. 2014;26:1363-75.

11. Fernández-Mayoralas $G$, Rojo-Pérez F, Martínez-Martín P, et al. Active ageing and quality of life: factors associated with participation in leisure activities among institutionalized older adults, with and without dementia. Aging Ment Health. 2015;19:1031-41.

12. Tam M. Active ageing, active learning: policy and provision in Hong Kong. Stud Contin Educ. 2011;33:289-99.

13. de São José JM, Timonen V, Amado CAF, Santos SP. A critique of the active ageing index. J Aging Stud. 2017;40:49-56. https://doi.org/10.1016/j.jaging. 2017.01.001.

14. Foster L, A Walker - The, 2014 U Active and successful aging: A European policy perspective. academic.oup.com. Accessed 18 Dec 2019.

15. Thanakwang K, Isaramalai S, Hatthakit U. Development and psychometric testing of the active aging scale for Thai adults. Clin Interv Aging. 2014;9:1211.

16. Rantanen T, Portegijs E, Kokko K, et al. Developing an assessment method of active aging: University of Jyvaskyla active aging scale. J Aging Health. 2019;31:1002-24.

17. Morrow-Howell N, Wang Y. Productive engagement of older adults: elements of a cross-cultural research agenda. Ageing Int. 2013;38:159-70.

18. Norouzian-Maleki S, Bell S, Hosseini SB, Faizi M. Developing and testing a framework for the assessment of neighbourhood liveability in two contrasting countries: Iran and Estonia. Ecol Indic. 2015;48:263-71. https:// doi.org/10.1016/j.ecolind.2014.07.033.

19. Lak A, Rashidghalam P, Myint PK, Baradaran HR. Comprehensive 5P framework for active aging using the ecological approach: an iterative systematic review. BMC Public Health. 2020. https://doi.org/10.1186/s12889019-8136-8

20. Salvo G, Lashewicz BM, Doyle-Baker PK, McCormack GR. Neighbourhood built environment influences on physical activity among adults: A systematized review of qualitative evidence. Int J Environ Res Public Health. 2018;15(5):897.

21. Scharlach AE, Lehning AJ, Scharlach AE (2016) Ageing-friendly communities and social inclusion in the united ageing-friendly communities and social inclusion in the United States of America. cambridge.org 110-136. https:// doi.org/10.1017/S0144686X12000578.

22. Alley D, Liebig P, Pynoos J, et al. Creating elder-friendly communities. J Gerontol Soc Work. 2007:49:1-18. https://doi.org/10.1300/J083v49n01_01. 
23. Barnett DW, Barnett A, Nathan A, et al. Built environmental correlates of older adults' total physical activity and walking: a systematic review and meta-analysis. Int J Behav Nutr Phys Act. 2017;14:103. https://doi.org/10. 1186/s12966-017-0558-z.

24. De Souza LNN, De Carvalho PHB, Ferreira MEC. Quality of life and subjective well-being of physically active elderly people: a systematic review. J Phys Educ Sport. 2018;18:1615-23. https://doi.org/10.7752/jpes. 2018.03237

25. Annear M, Keeling S, Wilkinson T, et al. Environmental influences on healthy and active ageing: a systematic review. Ageing Soc. 2014;34:590-622. https://doi.org/10.1017/S0144686X1200116X.

26. Rimmer JH. Use of the ICF in identifying factors that impact participation in physical activity/rehabilitation among people with disabilities. Disabil Rehabil. 2006;28:1087-95. https://doi.org/10.1080/09638280500493860.

27. Garcia MA, Angel JL, Angel RJ, et al. Acculturation, gender, and active life expectancy in the Mexican-origin population. J Aging Health. 2015;27:124765. https://doi.org/10.1177/0898264315577880.

28. Mendoza-Núñez VM, de la Luz Martínez-Maldonado M, Correa-Muñoz E. Implementation of an active aging model in Mexico for prevention and control of chronic diseases in the elderly. BMC Geriatr. 2009;9:40. https://doi. org/10.1186/1471-2318-9-40.

29. da Silva W, Barbosa K, de Oliveira F, et al. Personal and behavioral determinants of active aging. Int Arch Med. 2016;9.

30. Aird RL, Buys L. Active aging: Exploration into self-ratings of "being active," out-of-home physical activity, and participation among older australian adults living in four different settings. J Aging Res. 2015;2015. https://doi. org/10.1155/2015/501823.

31. Roberts E, Bishop A, Ruppert-Stroescu M, et al. Active aging for L.I.F.E. Top Geriatr Rehabil. 2017;33:211-22. https://doi.org/10.1097/TGR. 0000000000000157.

32. $\mathrm{Xu}, J \mathrm{~A}$ Good Place to Age in Place? Exploring the relationships between the built environment, activity participation and healthy aging. 2018. (Doctoral dissertation).

33. Filiatrault J, Bélanger $E$, Zunzunegui MV, et al. An empirical comparison of different models of active aging in Canada: the international mobility in aging study. Gerontologist. 2015. https://doi.org/10.1093/geront/gnv126.

34. Cerin E, Nathan A, van Cauwenberg J, et al. The neighbourhood physical environment and active travel in older adults: a systematic review and meta-analysis. Int J Behav Nutr Phys Act. 2017;14(1):1-23.

35. Plouffe $L$, Kalache A. Towards global age-friendly cities: determining urban features that promote active aging. J Urban Heal. 2010;87:733-9. https://doi. org/10.1007/s11524-010-9466-0.

36. Nyunt MSZ, Shuvo FK, Eng JY, et al. Objective and subjective measures of neighborhood environment (NE): relationships with transportation physical activity among older persons. Int J Behav Nutr Phys Act. 2015;12:108. https://doi.org/10.1186/s12966-015-0276-3.

37. Clarke P, George LK. The role of the built environment in the disablement process. Am J Public Health. 2005;95:1933-9. https://doi.org/10.2105/AJPH. 2004.054494.

38. Morris KS, McAuley E, Motl RW. Self-efficacy and environmental correlates of physical activity among older women and women with multiple sclerosis. Health Educ Res. 2008;23:744-52. https://doi.org/10.1093/her/cym067.

39. DS, HA, BG-C, et al. The built environment and depression in later life: the health in men study. Am J Geriatr Psychiatry. 2011;19:461-70.

40. Roelofsen P. Healthy ageing and the built environment. Intell Build Int 2014;6:3-10. https://doi.org/10.1080/17508975.2013.775097.

41. Quirk H, Crank H, Harrop D, et al. Understanding the experience of initiating community-based physical activity and social support by people with serious mental illness: a systematic review using a metaethnographic approach. Syst Rev. 2017;6:214. https://doi.org/10.1186/ s13643-017-0596-2.

42. Rantanen T, Saajanaho M, Karavirta L, et al. Active aging - resilience and external support as modifiers of the disablement outcome: AGNES cohort study protocol. BMC Public Health. 2018;18:565. https://doi.org/10.1186/ s12889-018-5487-5.

43. Kwok JYC, Ng KCH. User friendly living environmental research and Design for Older People. In: Designing inclusive futures. London: Springer London; 2008. p. 261-72.

44. Yung EHK, Conejos S, Chan EHW. Social needs of the elderly and active aging in public open spaces in urban renewal. Cities. 2016;52:114-22. https://doi.org/10.1016/j.cities.2015.11.022.
45. Cunningham GO, Michael YL. Concepts guiding the study of the impact of the built environment on physical activity for older adults: a review of the literature. Am J Health Promot. 2004;18:435-43. https://doi.org/10.4278/ 0890-1171-18.6.435.

46. Temelová J, Dvoráková N. Residential satisfaction of elderly in the city Centre: the case of revitalizing neighbourhoods in Prague. Cities. 2012;29: 310-7. https://doi.org/10.1016/j.cities.2011.11.015.

47. Afacan Y. Elderly-friendly inclusive urban environments: learning from Ankara. Open House Int. 2013;38:52-63.

48. Elsawahli H, Shah Ali A, Ahmad F, Al-Obaidi KM. Evaluating potential environmental variables and active aging in older adults for age-friendly neighborhoods in Malaysia. J Hous Elderly. 2017;31:74-92. https://doi.org/10. 1080/02763893.2016.1268560.

49. Tiraphat S, Peltzer K, Thamma-Aphiphol K, Suthisukon K. The role of agefriendly environments on quality of life among thai older adults. Int J Environ Res Public Health. 2017;14. https://doi.org/10.3390/ijerph14030282.

50. Noguchi M, Ma N, Woo C, et al. The usability study of a proposed environmental experience design framework for active ageing. Buildings. 2018:8:167. https://doi.org/10.3390/buildings8120167.

51. Clarke P, Nieuwenhuijsen ER. Environments for healthy ageing: a critical review. Maturitas. 2009;64:14-9.

52. Swallow D, Cambridge $H$, Cinderby $S$, et al. Co-designing urban living solutions to improve older People's mobility and well-being. J Urban Heal. 2018;95:409-22. https://doi.org/10.1007/s11524-018-0232-z.

53. Sonmez Turel H, Malkoc Yigit E, Altug I. Evaluation of elderly people's requirements in public open spaces: a case study in Bornova District (Izmir, Turkey). Build Environ. 2007:42:2035-45. https://doi.org/10.1016/j.buildenv. 2006.03.004.

54. Aneshensel CS, Harig F, Wight RG. Aging, neighborhoods, and the built environment. In: Handbook of aging and the social sciences: eighth edition; 2015. p. 315-35.

55. Eisenberg $Y$, Vanderbom KA, Vasudevan $V$. Does the built environment moderate the relationship between having a disability and lower levels of physical activity? A systematic review. Prev Med (Baltim). 2017;95:S75-84. https://doi.org/10.1016/j.ypmed.2016.07.019.

56. Karuppannan S, Sivam A, Koohsari M, Sivam A. Does urban design influence physical activity in the reduction of obesity? Rev Evid. 2012;5:14-21.

57. Hunter RH, Sykes K, Lowman SG, et al. Environmental and policy change to support healthy aging. J Aging Soc Policy. 2011;23:354-71. https://doi.org/ 10.1080/08959420.2011.605642.

58. Lehne G, Bolte G. Equity impact of interventions to promote physical activity in older adults: protocol for a systematic review. Syst Rev. 2016;5:17. https://doi.org/10.1186/s13643-016-0194-8.

59. EC, RR, Tziraki C. AO - Chrysikou EO http://orcid. org/000.-0002-7894-6053 (2016) Perspectives on the role and synergies of architecture and social and built environment in enabling active healthy aging. J Aging Res 2016: 6189349. https://doi.org/10.1155/2016/6189349.

60. Keysor JJ, Jette AM, Lavalley MP, et al. Community environmental factors are associated with disability in older adults with functional limitations: the (MOST) study. J Gerontol - Ser A Biol Sci Med Sci. 2010;65(A):393-9. https:// doi.org/10.1093/gerona/glp182.

61. Bauman A, Merom D, Bull FC, et al. Updating the Evidence for Physical Activity: Summative Reviews of the Epidemiological Evidence, Prevalence, and Interventions to Promote "Active Aging". Gerontologist. 2016;56:S26880. https://doi.org/10.1093/geront/gnw031.

62. Santinha G, Costa C, Diogo S. How are local policies promoting older People's mobility? A case study. Urban Sci. 2018;2:63. https://doi.org/10. 3390/urbansci2030063.

63. Li S-C, Lindenberger U, Hommel B, et al. Transformations in the couplings among intellectual abilities and constituent cognitive processes across the life span. Psychol Sci. 2004;15:155-63. https://doi.org/10.1111/j.0956-7976. 2004.01503003.x.

64. Michael YL, Green MK, Farquhar SA. Neighborhood design and active aging. Health Place. 2006;12:734-40. https://doi.org/10.1016/J. HEALTHPLACE.2005.08.002.

65. MJK, SM, KV, et al. Public open space, physical activity, urban design and public health: concepts, methods and research agenda. Heal Place. 2015;33: 75-82. https://doi.org/10.1016/j.healthplace.2015.02.009.

66. Nagel CL, Carlson NE, Bosworth M, Michael YL. The relation between neighborhood built environment and walking activity among older adults. Am J Epidemiol. 2008;168:461-8. https://doi.org/10.1093/aje/kwn158. 
67. Fadda G, Cortés A, Olivi A, Tovar M. The perception of the values of urban space by senior citizens of Valparaiso. J Aging Stud. 2010;24:344-57. https:// doi.org/10.1016/j.jaging.2010.07.001.

68. Clarke P, Gallagher NA. Optimizing mobility in later life: the role of the urban built environment for older adults aging in place. J Urban Heal. 2013; 90:997-1009. https://doi.org/10.1007/s11524-013-9800-4.

69. Clarke P, Ailshire JA, Lantz P. Urban built environments and trajectories of mobility disability: findings from a national sample of community-dwelling American adults (1986-2001). Soc Sci Med. 2009;69:964-70. https://doi.org/ 10.1016/j.socscimed.2009.06.041.

70. Van Cauwenberg J, Van Holle V, De Bourdeaudhuij I, et al. Neighborhood walkability and health outcomes among older adults: the mediating role of physical activity. Heal Place. 2016;37:16-25. https://doi.org/10.1016/j. healthplace.2015.11.003.

71. Andersson JE. Architecture for the silver generation: exploring the meaning of appropriate space for ageing in a Swedish municipality. Heal Place. 2011; 17:572-87. https://doi.org/10.1016/j.healthplace.2010.12.015.

72. Kerr J, Rosenberg D, Frank $L$. The role of the built environment in healthy aging. J Plan Lit. 2012;27:43-60. https://doi.org/10.1177/0885412211415283.

73. Borst HC, Graham JMA, van Dongen JEF, et al. Influence of environmental street characteristics on walking route choice of elderly people. J Environ Psychol. 2009;29:477-84. https://doi.org/10.1016/j.jenvp.2009.08.002.

74. Chan AC-M, Cao T. Age-friendly Neighbourhoods as civic participation: implementation of an active ageing policy in Hong Kong. J Soc Work Pract. 2015;29:53-68. https://doi.org/10.1080/02650533.2014.993947.

75. Sugiyama T, Thompson CW. Outdoor environments, activity and the wellbeing of older people: Conceptualising environmental support. Environ Plan A. 2007;39:1943-60. https://doi.org/10.1068/a38226.

76. Woo J, Chan R, Leung J, Wong M. Relative contributions of geographic, socioeconomic, and lifestyle factors to quality of life, frailty, and mortality in elderly. PLoS One. 2010;5:e8775. https://doi.org/10.1371/journal.pone. 0008775.

77. Li F, Fisher KJ, Brownson RC, Bosworth M. Multilevel modelling of built environment characteristics related to neighbourhood walking activity in older adults. J Epidemiol Community Health. 2005;59:558-64.

78. Veitch J, De Bourdeaudhuij I, Ghekiere A, et al. Park characteristics preferred for adolescent park visitation and physical activity: a choice-based conjoint analysis using manipulated photographs. Landsc Urban Plan. 2018;178:14455. https://doi.org/10.1016/j.landurbplan.2018.05.017.

79. SteelSteels S. Key characteristics of age-friendly cities and communities: A review. Cities. 2015;47:45-52. https://doi.org/10.1016/j.cities.2015.02.004.

80. Rioux $L$, Werner C. Residential satisfaction among aging people living in place. J Environ Psychol. 2011;31:158-69. https://doi.org/10.1016/j.jenvp. 2010.12.001.

81. Garin N, Olaya B, Miret M, et al. Built environment and elderly population Health: a comprehensive literature review. Clin Pract Epidemiol Ment Heal. 2014;10:103-15. https://doi.org/10.2174/1745017901410010103.

82. TG, AWT, AP. A population-based survey of factors relating to the prevalence of falls in older people. Gerontology. 2005;51:340-5.

83. $\mathrm{RM}, \mathrm{AC}, \mathrm{CM}, \mathrm{T} \varnothing$. Prevalence, awareness, treatment and control of hypertension in the elderly population of Singapore. Hypertens Res. 2010; 33:1223-31. https://doi.org/10.1038/hr.2010.177.

84. Mishra V. Effect of indoor air pollution from biomass combustion on prevalence of asthma in the elderly. Environ Health Perspect. 2003;111:71-8.

85. Zanjari N, Sani MS, Chavoshi MH, et al. Successful aging as a multidimensional concept: an integrative review. Med J Islam Repub Iran. 2017;31:686-91.

86. Yen $\mathrm{IH}$, Anderson LA. Built environment and mobility of older adults: important policy and practice efforts. J Am Geriatr Soc. 2012;60:951-6. https://doi.org/10.1111/j.1532-5415.2012.03949.x.

87. Mendoza-Ruvalcaba NM, Fernández-Ballesteros R. Effectiveness of the vital aging program to promote active aging in Mexican older adults. Clin Interv Aging. 2016;11:1631-44. https://doi.org/10.2147/CIA.S102930.

88. Mokaberian M, Kashani V, Kashani K, Tajari SN. Comparison of the happiness of active and passive elderly women and men in Tehran. Growth Mobil J. 2014;6:183-94. https://doi.org/10.22059/JMLM.2014.50456.

89. Yur'yev A, Leppik L, Tooding L-M, et al. Social inclusion affects elderly suicide mortality. Int Psychogeriatrics. 2010;22:1337-43. https://doi.org/10. 1017/S1041610210001614.

90. Mendes FR. Active ageing: a right or a duty? Heal Sociol Rev. 2013;22:17485. https://doi.org/10.5172/hesr.2013.22.2.174.
91. Vandenbroucke F. Social justice and individual ethics in an open society: Equality, responsibility, and incentives. Springer Science \& Business Media; 2012.

92. Del Barrio E, Marsillas S, Buffel T, et al. From active aging to active citizenship: the role of (age) friendliness. Soc Sci. 2018;7:134. https://doi.org/ 10.3390/socsci7080134.

93. Hanson E, Magnusson L, Arvidsson H, et al. Working together with persons with early stage dementia and their family members to design a userfriendly technology-based support service. Dementia. 2007;6:411-34. https:// doi.org/10.1177/1471301207081572.

94. McGarry P, Morris J. A great place to grow older: a case study of how Manchester is developing an age-friendly city. Work with Older People. 2011;15:38-46. https://doi.org/10.5042/wwop.2011.0119.

95. Zeitler E, Buys L, Aird R, Miller E. Mobility and active ageing in suburban environments: findings from in-depth interviews and person-based GPS tracking. Curr Gerontol Geriatr Res. 2012;2012:1-10. https://doi.org/10.1155/ 2012/257186.

96. Galea S, Freudenberg N, Vlahov D. Cities and population health. Soc Sci Med. 2005;60:1017-33. https://doi.org/10.1016/J.SOCSCIMED.2004.06.036.

97. Alpay LL, Toussaint PJ, Ezendam NPM, et al. Easing internet access of health information for elderly users. Health Informatics J. 2004;10:185-94. https:// doi.org/10.1177/1460458204045416

98. Masotti PJ, Fick R, Johnson-Masotti A, MacLeod S. Healthy naturally occurring retirement communities: a low-cost approach to facilitating healthy aging. Am J Public Health. 2006;96:1164-70. https://doi.org/10.2105/ AJPH.2005.068262

99. Paganini-Hill A. Aging in place in a retirement community: $90+$ year olds. J Hous Elderly. 2013;27:191-205. https://doi.org/10.1080/02763893.2012. 754822.

100. Tam M. A model of active ageing through elder learning: the elder academy network in Hong Kong. Educ Gerontol. 2013;39:250-8. https://doi. org/10.1080/03601277.2013.750931.

101. Taraghi Z, llali ES. A comparison of older adults' and managers' attitudes towards age-Friendly City indexes. Salmand. 2018:236-49. https://doi.org/10. 32598/sija.13.2.236

102. Levasseur $M$, Dubois MF, Généreux $M$, et al. Capturing how age-friendly communities foster positive health, social participation and health equity: a study protocol of key components and processes that promote population health in aging Canadians. BMC Public Health. 2017;17. https://doi.org/10. 1186/s12889-017-4392-7.

103. Lui C-W, Everingham J-A, Warburton J, et al. What makes a community agefriendly: a review of international literature. Australas J Ageing. 2009:28:11621. https://doi.org/10.1111/j.1741-6612.2009.00355.x.

104. Temelová J, Slezáková A. The changing environment and neighbourhood satisfaction in socialist high-rise panel housing estates: the timecomparative perceptions of elderly residents in Prague. Cities. 2014;37:8291. https://doi.org/10.1016/j.cities.2013.12.002.

105. Tzoulas K, Kaźmierczak A, James $P$, et al. Promoting ecosystem and human health in urban areas using Green infrastructure: a literature review. Landsc Urban Plan. 2007;81:167-78. https://doi.org/10.1016/j. landurbplan.2007.02.001.

106. Alidoust S, Bosman C. Planning for an ageing population: links between social health, neighbourhood environment and the elderly. Aust Plan. 2015; 52:177-86. https://doi.org/10.1080/07293682.2015.1034145.

107. Preston CC, Colman AM. Optimal number of response categories in rating scales: reliability, validity, discriminating power, and respondent preferences. Acta Psychol. 2000;104:1-15.

108. Woodcock T, Adeleke Y, Goeschel C, et al. A modified Delphi study to identify the features of high quality measurement plans for healthcare improvement projects. BMC Med Res Methodol. 2020;20:1-9.

109. Dalkey N. The Delphi method: An experimental study of group opinion. (No. RM-5888-PR). RAND CORP SANTA MONICA CALIF; 1969.

110. Hsu C-C, Sandford BA. The Delphi technique: making sense of consensus. Pract assessment, Res Eval. 2007;12:1-8.

111. Okoli C, Pawlowski SD. The Delphi method as a research tool: an example, design considerations and applications. Inf Manag. 2004;42:15-29.

112. Peffers K, Tuunanen T. Planning for IS applications: a practical, information theoretical method and case study in mobile financial services. Inf Manag. 2005;42:483-501.

113. Ludwig B. Predicting the future: have you considered using the Delphi methodology. J Ext. 1997;35:1-4. 
114. Esmaeilpoorarabi N, Yigitcanlar T, Guaralda M, Kamruzzaman M. Evaluating place quality in innovation districts: a Delphic hierarchy process approach. Land Use Policy. 2018;76:471-86. https://doi.org/10. 1016/.landusepol.2018.02.027.

115. Delbecq AL, de Ven AH, Gustafson DH. Group techniques for program planning: a guide to nominal group and Delphi processes. Glenview: Scott Foresman; 1975

116. Paúl C, Ribeiro O, Teixeira L. Active ageing: an empirical approach to the WHO model. Curr Gerontol Geriatr Res. 2012;2012:1-10. https://doi.org/10. 1155/2012/382972.

117. Society ST-A\&. 1999 undefined A culturally-relevant theoretical framework for the study of successful ageing. cambridge.org. Accessed 18 Dec 2019.

118. Marsillas S, De Donder L, Kardol T, et al. Does active ageing contribute to life satisfaction for older people? Testing a new model of active ageing. Eur J Ageing. 2017;14:295-310. https://doi.org/10.1007/s10433-017-0413-8.

119. Boudiny K, Mortelmans D. A critical perspective: towards a broader understanding of'active ageing'. E-journal Appl Psychol. 2011;7:8-14.

120. Berg Al. Life satisfaction in late life: markers and predictors of level and change among 80+ year olds, Gothenburg: Department of Psychology; Psykologiska institutionen. Sweden: University of Gothenburg; 2008. (Dissertation).

121. Society ST-A\&, 1999 undefined A culturally-relevant theoretical framework for the study of successful ageing. cambridge.org. Accessed 18 Dec 2019.

122. Oswald F, Jopp D, Rott C, et al Is aging in place a resource for or risk to life satisfaction? academic.oup.com. Accessed 18 Dec 2019.

123. Walker A. A strategy for active ageing. Int Soc Secur Rev. 2002;55:121-39.

\section{Publisher's Note}

Springer Nature remains neutral with regard to jurisdictional claims in published maps and institutional affiliations.

Ready to submit your research? Choose BMC and benefit from:

- fast, convenient online submission

- thorough peer review by experienced researchers in your field

- rapid publication on acceptance

- support for research data, including large and complex data types

- gold Open Access which fosters wider collaboration and increased citations

- maximum visibility for your research: over $100 \mathrm{M}$ website views per year

At $\mathrm{BMC}$, research is always in progress.

Learn more biomedcentral.com/submissions 